\title{
A Literature Review on the Definition of Corruption and Factors Affecting the Risk of Corruption
}

\author{
Xizi Liu \\ School of Government, Beijing Normal University, Beijing, China \\ Email: louise_liu@mail.bnu.edu.cn \\ Received 24 May 2016; accepted 25 June 2016; published 28 June 2016 \\ Copyright (C) 2016 by author and Scientific Research Publishing Inc. \\ This work is licensed under the Creative Commons Attribution International License (CC BY). \\ http://creativecommons.org/licenses/by/4.0/ \\ c) (i)

\section{Abstract}

To choose a set of definitions on corruption and summarize the quantitative measures of corruption, this article gives some comments on a wealth of global indicators of corruption. Based on the academic research, the factors of corruption could be mapped in three levels: macro, meso and micro. In the past, most literatures pay attention to the macro factors to study the relationship between corruption, development, culture and politics. In the meso-level, internal system construction is the most important factors on corruption. More and more scholars tend to use the real raw data rather than the perception of data to study the corruption of a certain country or region. Micro factors research on corruption will become increasingly popular in the future.

\section{Keywords}

\section{Corruption, Factors, Macro, Meso, Micro}

\section{Introduction}

The increasingly anti-corruption efforts of the Chinese Communist Party and the government make Chinese scholars pay much attention to the corruption. More than 49 thousands people have been punished for an eightpoint regulation in 2015, these violators were found to have been involved in 37 thousands cases during the campaign. In fact, the problem of corruption is always with China since the founding of the People's Republic. More generally, the problem can trace back to ancientry coming out with the country. In past research, scholars have made abundant achievements about corruption, especially in the definition and related clinical factors on corruption.

There are various definitions of corruption in theory field. The most widely used definition is "corruption is 
taken to be the abuse of public office for private benefit”, which has pointed out the nuclear connotation of corruption. According to different studying objects and purposes, the precise definition and measurement could distinguish between different issues. This article gives a review of the factors affecting the risk of corruption from the macro, meso and micro levels. Each factor alone affects the risk of corruption and the influence will not just flow one way, hence the interaction among all factors was very complex. I hope the literature review would provide worthy reference and be helpful for the following academician.

\section{What Is Corruption?}

\subsection{Definition of Corruption}

Rousseau once pointed out that the legitimacy of the national public power comes from the people. The government is the executor of the sovereign. Its power comes from the people's trust. When the use of public power deviate from the original track, being abused, corruption problems arise. It accords with the definition of "the abuse of public office for private benefit". This definition is also the most widely used by foreign scholars on the concept of corruption ${ }^{1}$. The research of corruption as a specific concept of public administration in China began in the 1980s and 1990s. Wang Huning and Huang Bai Lian defines corruption as non-public use of public power (abuse and unfair exchange). Most scholars believe that corruption is the only government official acts of abuse of power [1]. He (2003) thinks from this concept that corruption includes the subject of corruption, motivation (purpose), means, the way and the consequences and puts the negative corruption into the scope of corruption. He particularly points out that a lot of corruption is hiding under the cloak of acts of abuse of power with violation of the established codes of ethics [2].

At present Chinese and foreign academic circles have not formed a unified definition of the "corruption". It is usually defined as the corruption of public officials in the state organs use power in the hands for bribery, corruption, extortion, fraud and other acts. But this term includes many aspects of economy, politics, culture, morality, law and so on. In recent years, the extension of corruption has continued to expand. The main body of corruption is no longer confined to the national institution. More subjects are included. For example "academic corruption” refers to the corruption in universities and research institutions. The forms of corruption include not only public officials’ personal gain behavior but also interest exchange process, such as nepotism, nonfeasance and disposal of public resources [3].

Bussell (2015) pointed out that there are many ways to define corruption in detail. But no definition can be applied to all research purposes [4]. Therefore, first of all the diversity of the corruption's content should be recognized. From the research intent, the appropriate concept of corruption and measurement methods are selected. This approach is more adapted to the current study for the purpose to give a definition of corruption is to do better in scholarly studies.

\subsection{Determination of Corruption}

The transnational research of corruption usually adopts the corruption index provided by the international database, such as CPI of Transparency International, WBES of World Bank Institute and Corruption Index of Intelligence Unit. Most of the index comes from a survey of people, businesses, or experts [5]. Most of these composite index, reflecting the various aspects of corruption, describe the general situation of corruption from the overall and provide a great convenience for the evaluation of corruption and empirical research [6]. But the perception data reflects the ideas of data source on corruption and cannot guarantee that there is a link between the subjective indicators and the actual level of corruption. At the same time, due to the existence of the same index in different years of the composition and weight adjustment, part of the index's the time longitudinal comparability is poor, so there is a certain misleading in the time series analysis.

For the foregoing reasons, some scholars choose practice cases instead of international database in quantitative research. In the study of the relationship between economic and political corruption, Ruske (2015) used individual corruption data of US Congress members provided by CREW [7]. Many scholars use the objective data to study the corruption problem between regions and achieved great fruits in China. On the research of government size and corruption of market and local regions, Zhou and Tao (2009) use the number of corruption cases

${ }^{1}$ World Bank: Corruption is the abuse of public power for private benefit. Similar to Corruption is the abuse of public power for private gain. This definition has been used by many scholars on the concept of corruption See, e.g., Olken (2007), Bardhan (2006), Jain (2001), and Rose-Ackerman (2011). 
of officials of the state organs as the index to measure the degree of corruption of the state organs [8]. Li and Zhang (2014) use the proportion of the number of local officials (people/million) accounted the number of corruption cases [9]. Gong, Wu (2012), Qiao (2013) take the method of direct collection of corruption cases to conduct empirical research. These scholars' attempts provide a powerful reference for the more comprehensive and more objective study of corruption in China [10] [11].

There is no unified view regarding the determination of corruption achieved yet. In the literature of recent years, scholars usually use a number of corrupt data base provided by agencies to measure corruption level in order to be more accurately. At the same time, more and more scholars tend to start from the objective index, the real case, a specific country and a case research of a region, because variable of each country is doubtful in horizontal comparison in the international corruption research.

\section{Research Progress on the Related Factors of Corruption}

The research of related factors of corruption is the most important aspect in the corruption study. From the macro level, the corruption level of a country to a certain extent should determine by the country's economic, political and cultural level. At the same time, corruption has effect on these three parties. From the medium view, system construction and execution of the decentralization degree between the national agencies, recruitment, appointment, compensation and punishment not only affect the bud of corruption, but also has a significant impact on the spread of corruption. From the microscopic level, even when the individual is in the same or similar external environment or under the same system, there may be significant differences in the risk of corruption due to the influence of individual gender, education, values and other factors. This section will start from the three levels of macro factors, meso factors and micro factors and summarizes the existing research results of the related factors of corruption.

\subsection{Macro Factors Affecting the Risk of Corruption}

The growing importance of corruption is based on the consensus that the development of the country needs good governance. So in the study of corruption related factors, the relationship between corruption and the development is the first to enter the vision's field. Mauro (1995) analyzed the corrupt data of over 70 countries in the world and concluded that corruption led to low investment and affected economic growth [12]. Treisman (2000) found the causal relationship between the economic development and reciprocal causation of corruption through the study of the per capita GDP [13]. Compared with the developed countries, the poor countries are more common. Bardhan (1997) pointed out that corruption had a devastating effect on the economy, while it cannot be denied that corruption has a positive meaning in some areas [14]. Farooq and Shahbaz et al. (2013) shows that corruption is an obstacle to economic growth by building a time series model [15]. The relationship between inequality and corruption is also controversial. By studying the cross section data of 37 countries (using the Gini coefficient as the measurement scale), Gupta and Davoodi et al. (1998) pointed out that corruption has increased the income inequality and increased poverty [16].

Culture and politics are also closely related to corruption. The colonial culture and its political characteristics are the main reasons for the serious corruption in the colonial countries. Through summary of the vague and frequent crossed boundaries during most time in eighteenth century between the position extra allowance official recognized and economic benefits through positions in England, Pavarala and Malik (2007) try to prove that under its rule colonialism is "unique, depending on circumstances, indirect, incomplete, and often contradictory". Colonial officials tended to use special treatment or privilege for their own benefit. But the average citizen tribute to them "modestly" [17]. Yang (2014) that excessive emphasis on consanguineous ethic tradition of "evil" caused many troubles today. Men are not what they were in times past and the general moves are getting worse and worse. He thought that excessive emphasis on "evil" of consanguineous ethic tradition made corruption popular nowadays [18]. Treisman (2000) believed that religious traditions and corruption are related [13]. This is because the religious tradition often determines the people's attitude towards the social class. At the same time religion plays the role of monitoring and condemning the abuse of power.

\subsection{Meso Factors Affecting the Risk of Corruption}

The meso factors that influence the risk of corruption mainly emphasize the influence of the internal system construction on corruption. A large number of academic research results show that the organization of decentra- 
lization is conducive to curb corruption. Pan, He and Yuan (2011) analyzed the various impact of fiscal decentralization on regional corruption mechanism by using the provincial panel data of China during 1999 and 2008 [19]. They pointed out that fiscal decentralization can restrain the corruption level in the region. Sun and Johnston (2009) analyzed the institutional differences between China and India. They thought that China delegated to the local authority, but the decision-making power is still in the hands of every level of government or stateowned enterprises. So the local authority appeared [20]. While most of the private enterprises in India are in the hands of some noble class and some families. Political donors who seek power will use sponsorship to retain power.

Different scholars hold different views on whether the competition will be conducive to reducing corruption. Ades and Tella (1999) believes that competition reduces corporate profits and then there is no excess profits to bribe [21]. So the introduction of competition is conducive to curb corruption. Svensson (2005) summed up the the study of Tella, Bliss, Shleifer, Vishny, Soto De and other scholars. He thought the relationship between profit and corruption is very complicated and not easy to analyze [22]. Although there is a lot of evidence show a negative correlation among corruption, deregulation, simplifying regulations and the introduction, it may also open the door to corruption. It is very difficult to find the balance between the two. Ades and Tella (1999), Treisman (2000) advocated that improving the level of opening to the outside world is conducive to reducing corruption.

When the system is constructed, it is an important means to clear and strengthen the consciousness of main body responsibility. Tavits (2007) proveed that the political system to affect the level of corruption through a clear responsibility [23]. The key assumption is that when the political system is very clear about the responsibilities of officials in the region, officials will pursue a good policy and reduce corruption under pressure. Ferraz and Finan (2009) conducted a study of the relationship between the election system and corruption based on local audit data. The results show that the possibility of resources occupation of reappointment mayor is $27 \%$ less than mayor without reappointment. This effect is more obvious in those cities with low information transparency and low judicial punishment [24]. Li and Zhang (2014) made research by using micro enterprise data of large sample. They got that the relationship between local officials and corruption, corporate R\&D investment and corruption was significantly inverted e curve. That is to say, appropriate extension of the term of officials and a moderate level of corruption are conducive to the promotion of enterprise R\&D investment. While long term and excessive levels of corruption will inhibit the area of corporate R\&D investment [9]. Nie (2014), based on the research of corruption cases of prefectural officials and above, proved that the political cycle represented by the main political events will have a significant impact on the anti-corruption efforts [25]. Keig, Brouthers and Marshall (2015) analyze the companies with more significant formal and informal corruption often lack the sense of social responsibility with application of institutional framework theory and then verified it [26].

How the compensation system affects the risk of corruption has also been widely discussed. Although the high salary system is frequently mentioned, Sosa (2004) explained the emergence of corruption through using the expected utility model of economics and deduced that policies to increase net income from potentially corrupt institutions are not only ineffective [27], but may also encourage corruption. Ivanyna and Rangazas (2015) proposed a different point of view. They used a dynamic general equilibrium model to quantify the impact of corruption and tax evasion of the fiscal policy and economic growth. At the time, they mentioned that when the public sector pay is high enough, the corruption and tax evasion will be eliminated. Total social welfare will be increased [28]. Gong and Wu (2012)'s results of the empirical study of China's actual showed that civil service pay level and corruption had no direct linear relationship. The effectiveness of salary is questionable [29].

\subsection{Micro Factors Influencing the Risk of Corruption}

Scholars also try to analyze the causes and mechanisms of corruption from the main body of the corrupt behavior. Dollar et al. (2001) is committed to studying the impact of gender on corruption earlier. They used International Country Risk Guide's corruption index to empirically analyze the relationship between gender and corruption. [30] The results show that the larger the number of women in the total number of government officials is, the lower the degree of corruption is. Sung (2003) believed that there may be a reverse causality. Regions with lower levels of corruption will limit male dominated social networks and provide more possibilities for women to get jobs [31]. There may be other factors that affect both of them. Based on the data provided by the European Commission and the QoG, Stensöta, Wängnerud and Svensson (2014) studied the relationship be- 
tween different gender and corruption in institutional logic. They found that the difference between men and women is derived from the asymmetry experience between men and women, not their basic properties. Compared to the bureaucracy, women in the electoral system play a more significant role in curbing corruption [32].

Gong and Wu (2012) study the case of more than 2800 reports. He found that bribery happens in divisional cadre and bureau-level cadres and they are the heads of governmental office [10]. Rosenblatt (2012) points out from the theory of social control that people in the social status of the dominant think they are in a superior position. It is more difficult to realize the corruption for them. This is because they have a strong awareness of the rights and have the desire to keep the main place. Even if this needs to take use of others [33]. Native Chinese scholar Chen (2013) also embarks from the social interaction theory. He, taking the data of 31 provinces of China in 2003-2007 as the sample, found that the rate of corruption among Chinese officials has a significant effect on the spread of the provinces [34]. The effect of this kind of infection mainly comes from the demonstration effect of official corruption. The focus of anti-corruption strategy may lie in the supervision and management of high-level officials.

\section{Conclusions}

It can be seen from the analysis of the existing literature that foreign scholars carry out a more detailed study from definition of corruption and related factors at the view of economics and sociology. Early corruption research results mainly focus on the national and institutional level and analyze the specific impact of various aspects of the economic and political and cultural system and corruption. Research results are rich with different focus. However, there is still a great controversy on whether these factors have a practical impact on corruption. Serrae (2006), according to the 16 factors, including the national innate endowment, colonialism, religion, open level and other factors, did the research of the overall sensitivity analysis based on Extreme-Bounds Analysis. Only 5 variables were found to have strong robustness with corruption. The scholars have carried on the reflection to the early research. The effectiveness of the early corruption index measurement and the international comparability of the macro data are studied and perfected [35]. From the latest research, it can be seen that scholars began to tend to use the real raw data rather than the perception of data to study the corruption of a certain country or region when they use empirical analysis method.

For the summary of domestic research achievements, the existing results are summarized in the empirical research part in this paper. Before 2011, Chinese intellectuals in the study of corruption in the empirical research results are less. The research methods are reasoning analysis and qualitative research method. The definition of corruption, the reason, the present situation, the power of anti-corruption and institutional anti-corruption are studied deeply. In recent years, a large number of quantitative researches on the causes of corruption appear. The data sources used in the research are almost provincial data. While the study on relationship between the individual factors and the risk of corruption, stops with a simple descriptive statistics. There are many aspects to be studied further. The trend of future in corruption' factors research will become increasingly important on meso factors and micro factors in the future.

\section{Acknowledgements}

This work was supported in part by the National Social Science Foundation of China (Grant No. 13AZD093 and 15BGL154). The views expressed herein are those of the authors and are not necessarily those of the National Social Science Foundation of China.

\section{References}

[1] Li, Y.L., Wu, S.J. and Hu, Y.M. (2011) A Review of Anti-Corruption Studies in Recent China. Chinese Public Administration, 11, 115-119.

[2] He, Z.K. (2003) Research in the Issues of Corruption and Combationg Corruption during Chinese Transition. Comparative Economic \& Social Systems, 1, 19-29.

[3] Otusany, O.J. (2011) Corruption as an Obstacle to Development in Developing Countries: A Review of Literature. Journal of Money Laundering Control, 14, 391-393.

[4] Bussell, J. (2015) Greed, Corruption, and the Modern State Essays in Political Economy. Edward Elgar, London, 22-32.

[5] Razafindrakoto, M. and Roubaud, F. (2010) Are International Databases on Corruption Reliable? A Comparison of 
Expert Opinion Surveys and Household Surveys in Sub-Saharan Africa. World Development, 38, 1057-1060. http://dx.doi.org/10.1016/j.worlddev.2010.02.004

[6] Xu, J. (2012) A Comparative Study on Corruption Indexes at Home and Abroad. Chinese Public Administration, 5, $110-114$.

[7] Ruske, R. (2015) Does Economics Make Politicians Corrupt? Empirical Evidence from the United States Congress. Kyklos, 68, 240-254. http://dx.doi.org/10.1111/kykl.12082

[8] Zhou, L.A. and Tao, J. (2009) Government Size, Market Development and Corruption. Economic Research Journal, 1, 57-69.

[9] Li, H.J. and Zhang, Z.Y. (2014) Local Official Tenure, Corruption and Firm R\&D Investment. Studies in Science of Science, 32, 744-757.

[10] Gong, T. and Wu, M.L. (2012) A Research Report on China’s Corruption Cases during 2000-2009: Empirical Analysis of Some 2800 Corruption Cases. Sociological Studies, 4, 204-246.

[11] Qiao, D.F. (2013) A Case Study of Corruption about the Head in the City since the Reform and Opening up-Based on the Case of Corruption in 142 Cities. Theory and Reform, 5, 65-71.

[12] Mauro, P. (1995) Corruption and Growth. The Quarterly Journal of Economics, 8, 1100. http://dx.doi.org/10.2307/2946696

[13] Treisman, D. (2000) The Causes of Corruption: A Cross-National Study. Journal of Public Economics, 76, $399-457$. http://dx.doi.org/10.1016/S0047-2727(99)00092-4

[14] Bardhan, P. (1997) Corruption and Development: A Review of Issues. Journal of Economic Literature, 35, $1320-1346$.

[15] Farooq, A., Shahbaz, M., Arouri, M. and Teulon, F. (2013) Does Corruption Impede Economic Growth in Pakistan? Economic Modelling, 35, 622-633. http://dx.doi.org/10.1016/S0047-2727(99)00092-4

[16] Gupta, S., Davoodi, H. and Alonso-Terme, R. (2002) Does Corruption Affect Income Inequality and Poverty? Economics of Governance, 3, 23-45. http://dx.doi.org/10.1007/s101010100039

[17] Pavarala, V. and Malik, K.K. (2007) Other Voices: The Struggle for Community Radio in India. Sage Publications, London, 290-295.

[18] Yang, J. (2014) The Cultural Roots of Corruption. Exploration and Free Views, 94-96.

[19] Pan, C.Y., He, L.X. and Yuan, C.S. (2011) Fiscal Decentralization and Corruption: An Empirical Study Based on China's Provincial Panel Data from 1999 to 2007. Contemporary Finance \& Economics, 38-46.

[20] Sun, Y. and Johnston, M. (2009) Does Democracy Check Corruption? Insights from China and India. Comparative Politics, 42, 1-19. http://dx.doi.org/10.5129/001041509X12911362972719

[21] Ades. A. and Tella, R.D. (1999) Rents, Competition, and Corruption. American Economic Review, 89, $982-993$. http://dx.doi.org/10.1257/aer.89.4.982

[22] Svensson, J. (2005) Eight Questions about Corruption. Journal of Economic Perspectives, 19, 19-42. http://dx.doi.org/10.1257/089533005774357860

[23] Tavits, M. (2007) Clarity of Responsibility and Corruption. American Journal of Political Science, 51, 38-46. http://dx.doi.org/10.1111/j.1540-5907.2007.00246.x

[24] Ferraz, C. and Finan, F. (2009) Electoral Accountability and Corruption: Evidence from the Audits of Local Governments. Working Paper 14937, 1-23.

[25] Nie, H.H. (2014) The Impact of Corruption on Economic Efficiency: A Survey. Chinese Review of Financial Studies, $13-23$.

[26] Keig, D.L., Brouthers, L.E. and Marshall. V.B. (2015) Formal and Informal Corruption Environments and Multinational Enterprise Social Irresponsibility. Journal of Management Studies, 52, 89-116. http://dx.doi.org/10.1111/joms.12102

[27] Sosa, L.A. (2004) Wages and Other Determinants of Corruption. Review of Development Economics, 8, 597-605. http://dx.doi.org/10.1111/j.1467-9361.2004.00255.x

[28] Ivanyna, M., Moumouras, A. and Rangazas, P. (2016) The Culture of Corruption, Tax Evasion, and Economic Growth. Economic Inquiry, 54, 520-542. http://dx.doi.org/10.1111/ecin.12228

[29] Gong, T. and Wu, M.L. (2012) The Effect of Pay Raises on Corruption Prevention: Evidence from the Chinese Public Sector. Comparative Economic \& Social Systems, 117-129.

[30] Dollar, D., Fisman, R., Gatti, R. and Rangazas, P. (2001) Are Women Really the "Fairer" Sex? Corruption and Women in Government. Journal of Economic Behavior \& Organization, 46, 423-429. http://dx.doi.org/10.1016/S0167-2681(01)00169-X 
[31] Sung, H.E. (2003) Fairer Sex or Fairer System? Gender and Corruption Revisited. Social Forces, 82, 703-723. http://dx.doi.org/10.1353/sof.2004.0028

[32] Stensöta, H.O., Wängnerud, L. and Svensson, R. (2014) Gender and Corruption: The Mediating Power of Institutional Logics. Governance, 28, 475-496. http://dx.doi.org/10.1111/gove.12120

[33] Rosenblatt, V., (2012) Hierarchies, Power Inequalities, and Organizational Corruption. Journal of Business Ethics, 111, 237-251. http://dx.doi.org/10.1007/s10551-012-1204-y

[34] Chen, G. (2013) The Negative Role Model of Corrupt High Government Officials in the Spread of Corruption: Evidence from China. Comparative Economic \& Social Systems, 154-164.

[35] Serrae, D. (2006) Empirical Determinants of Corruption: A Sensitivity Analysis. Public Choice, 126, $225-256$. http://dx.doi.org/10.1007/s11127-006-0286-4

\section{Submit or recommend next manuscript to SCIRP and we will provide best service for you:}

Accepting pre-submission inquiries through Email, Facebook, Linkedin, Twitter, etc A wide selection of journals (inclusive of 9 subjects, more than 200 journals)

Providing a 24-hour high-quality service

User-friendly online submission system

Fair and swift peer-review system

Efficient typesetting and proofreading procedure

Display of the result of downloads and visits, as well as the number of cited articles

Maximum dissemination of your research work

Submit your manuscript at: http://papersubmission.scirp.org/ 